\title{
Natural Area Weeds: Skunkvine (Paederia foetida) ${ }^{\mathbf{1}}$
}

\author{
K. A. Langeland, R. K. Stocker, and D. M. Brazis²
}

- Skunkvine is fast-growing and can adapt to a wide range of different light, soil, and salt conditions.

- It invades disturbed areas and undisturbed native plant communities, including sandhill, rockland hammock, upland mixed forest, swamps, and floodplains.

- This weed creates dense canopies, leading to damage or death of native vegetation (Figure 1).

- It has smothered out one of the remaining populations of the endemic, federally endangered Cooley's water willow.

- Skunkvine spreads by transport of rooted fragments and seeds.

- This weed is also found in landscapes.

Native to eastern and southern Asia, skunkvine is an invasive plant species introduced to the USDA Field Station near Brooksville (Hernando Co., FL) before 1897 (Morton 1976). By 1916, it was already reported as a troublesome weed in that area. It was noted as escaping to thickets and fence rows in peninsular Florida in 1933 (Small 1933). By 1977, it was considered an economically important weed (Reed 1977). In 1993, it was included on the Florida Exotic Pest Plant Council List of Invasive Species as a Category I, defined as "species that are invading and disrupting native plant communities in Florida." It was added to the Florida

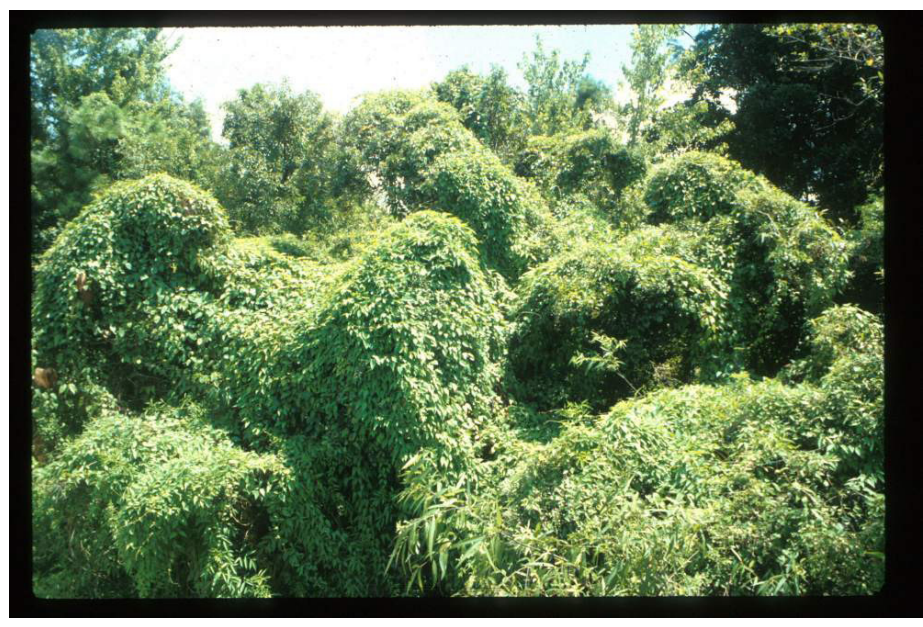

Figure 1. Skunkvine growing over native shrubs.

Noxious Weed List (5B-57.007 F.A.C.) in 1999, making it illegal to possess, move, or release in Florida.

Skunkvine is most common in west-central Florida but is also documented northward into Georgia (Wunderlin and Hansen 2008). It is also reported in Virginia, Louisiana, Texas, South Carolina, and the Hawaiian Islands (http:// www.eddmaps.org/distribution/). It is reported from natural areas in Hillsborough, Hernando, Pasco, Citrus, Marion, Sumter, Lake, Orange, and Polk Counties (Langeland et al. 2008).

1. This document is SS-AGR-80, one of a series of the Agronomy Department, Florida Cooperative Extension Service, Institute of Food and Agricultural Sciences, University of Florida. Originally published August 2000. Revised February 2013. Please visit the EDIS website at http://edis.ifas.ufl.edu.

2. K. A. Langeland, professor; R. K. Stocker, professor emeritus; and D. M. Brazis, former graduate assistant, Agronomy Department and Center for Aquatic and Invasive Plants; Florida Cooperative Extension Service, Institute of Food and Agricultural Sciences, University of Florida, Gainesville, FL 32611.

The use of trade names in this publication is solely for the purpose of providing specific information. UF/IFAS does not guarantee or warranty the products named, and references to them in this publication do not signify our approval to the exclusion of other products of suitable composition. 


\section{How to Identify Skunkvine}

- It has perennial twining vine from woody rootstock.

- Leaves are opposite (rarely in whorls of 3), oval to lanceshaped, and often lobed at the base. They grow $2-11 \mathrm{~cm}$ (1-4.3 in) long with conspicuous stipules (appendages at bases of leaves), and have leaf margins without teeth. The leaf surfaces can be hairy or non-hairy (Figure 2, Figure $5)$.

- Leaf stalks commonly grow to $6 \mathrm{~cm}$ (2.4 in) long.

- Leaves and stems have a disagreeable odor, especially when crushed.

- Flowers (appearing mostly in late summer and fall) are small and grayish pink or lilac in color. The flowers form in broad or long, "leafy," curving clusters. Petals join to form a tube (corolla), with usually five spreading lobes (the corolla is dense and hairy) (Figure 3, Figure 5).

- Fruit (persisting through winter) are shiny brown and nearly round, growing to $0.7 \mathrm{~cm}$ (0.3 in) wide. Each fruit has two seeds that are black, roundish, and often dotted with white, needle-shaped crystals (Figure 4, Figure 5).

- Sewer vine (P. cruddasiana), a serious (but less widespread) pest, is similar to skunkvine but has oval, flattened fruits and distinctly winged seeds.



Figure 2. Skunkvine leaves and stipules.

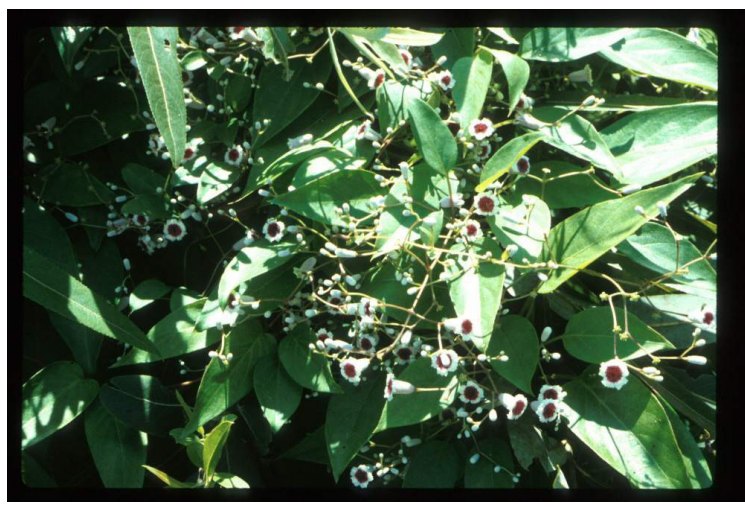

Figure 3. Skunkvine flowers.

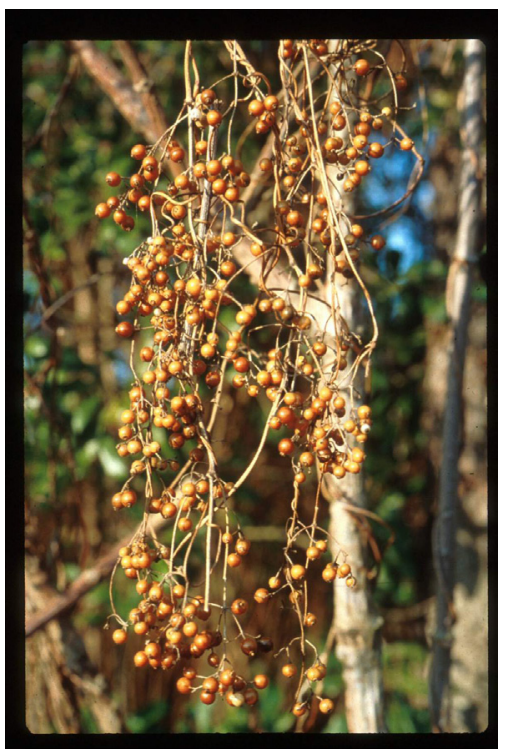

Figure 4. Mature skunkvine fruits.

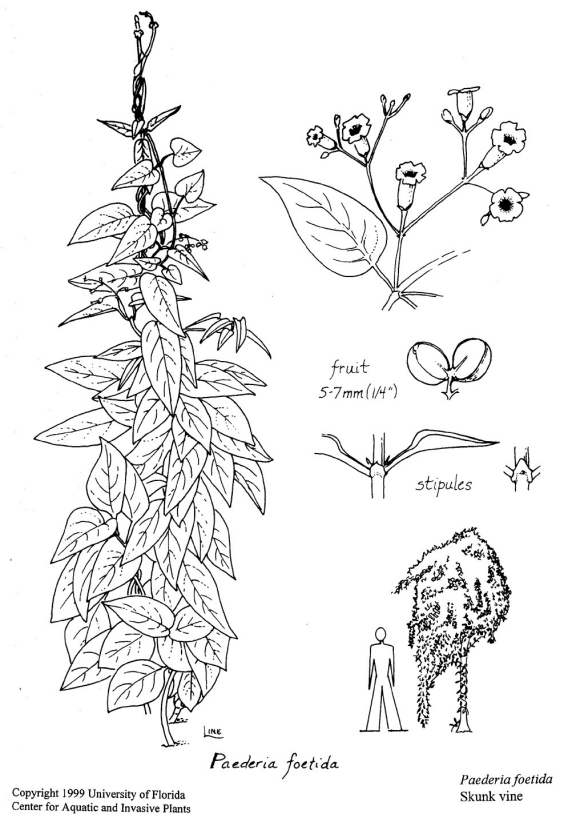

Figure 5. Line drawing of skunkvine. 


\section{Control}

Some hand removal of skunkvine in landscape situations will be necessary, but large-scale hand removal in natural areas has proven ineffective. Cut stems will die above, but regrow from below. Always be careful not to dispose of skunkvine where seeds can germinate or where stem fragments can take root. Flooding decreases vigor, but plants remain alive when submersed for at least 192 days. Herbicides that contain the active ingredients triclopyr amine, triclopyr ester, imazapic, and aminopyralid provide control (Table 1). Complete control may not be achieved with a single application; follow-up applications may be necessary. Avoid contact of herbicides with sensitive nontarget vegetation. Use herbicides according to all directions on the label.

\section{References}

Langeland, K. A., H. M. Cherry, C. M. McCormick, and K. A. Craddock Burks. 2008. Identification and Biology of Nonnative Plants in Natural Areas of Florida, $2^{\text {nd }}$ edition. SP-257. Gainesville: University of Florida Institute of Food and Agricultural Sciences.

Morton, J. F. 1976. "Pestiferous Spread of Many Ornamental and Fruit Species in South Florida." Proc. Fla. State Hort. Soc. 89:348-53.

Reed, C. F. 1977. Economically Important Foreign Weeds: Potential Problems in the United States. Ag. Handbook No. 498. Washington, D.C.: APHIS, USDA.

Small, J. K. 1933. Manual of the Southeastern Flora, Parts one and two. Chapel Hill, NC: University of North Carolina Press. Facsimile reprint 1972, New York: Hafner Publishing.

Wunderlin, R. P., and B. F. Hansen. 2008. Atlas of Florida Vascular Plants. Developed by S. M. Landry and K. N. Campbell for Florida Center for Community Design and Research. Tampa: University of South Florida Institute for Systematic Botany. http://www.plantatlas.usf.edu/.

Table 1. Herbicides for control of Skunkvine (Paederia foetida).

\begin{tabular}{|c|c|}
\hline Herbicide & Notes \\
\hline Triclopyr amine (31.8\% acid) & $\begin{array}{l}\text { Broadcast } 4-8 \text { pints per acre diluted in water or mix } 0.5 \% \text { solution and spray foliage } \\
\text { to wet. }\end{array}$ \\
\hline Triclopyr amine (8.8\% acid) & Mix 4 ounces per gallon of water and spray foliage to wet. \\
\hline Triclopyr amine $(0.8 \%$ acid $)$ & Spray foliage to wet with undiluted product. \\
\hline Triclopyr ester (43.6\% acid) & $\begin{array}{l}\text { Broadcast } 1.5-4.5 \text { pints per acre diluted in water or mix } 0.2 \%-0.6 \% \text { solution and } \\
\text { spray foliage to wet. }\end{array}$ \\
\hline Imazapic (22.2\% acid) & Mix $1.0 \%-1.5 \%$ solution and spray to wet foliage. \\
\hline Aminopyralid (21.1\% acid) & $\begin{array}{l}\text { Mix 4-7 ounces per } 100 \text { gallons of water (or equivalent, e.g., } 1.2-2.1 \mathrm{ml} / \mathrm{gal} ; 1 \mathrm{ml}=0.2 \\
\text { tsp) and spray foliage to wet. }\end{array}$ \\
\hline
\end{tabular}

